\title{
ОРТОДОНТІЯ
}

UDC 616.314.2-007.271-053.7:617.52:616-073.75

Drachevska I. Yu., Dmitriev M.O., Popova O.I., Chugu T.V., Gunas I.V.

\section{DETERMINATION OF NORMATIVE CEPHALOMETRIC PARAMETERS ACCORDING TO THE STEINER METHOD FOR UKRAINIAN YOUNG MEN AND YOUNG WOMEN WITH DIFFERENT FACE TYPES}

\author{
National Pyrogov Memorial Medical University, Vinnytsya, Ukraine
}

\section{Introduction}

The epidemiological situation regarding the most common pathologies of the dental-jaw system, namely orthodontic pathologies (occlusion, size and position of teeth, their absence, etc.) is still tense their prevalence is increasing, as evidenced by dental examinations of children in different countries. Thus, in the Kozhikode region (India) the prevalence of malocclusion among persons aged 10-12 years was $83.3 \%$, of which $69.8 \%$ had an occlusion of class I, $8.9 \%$ - class II, $4.1 \%$ - class III, $0.4 \%$ - reverse bite, $35.6 \%$ - increased bite, $0.29 \%$ - open bite, $7.2 \%$ - cross bite [1].

For adequate prognosis and planning of odontological treatment, doctors have been using the cephalometric method of lateral teleradiography for many years, which has also proven itself in other fields of medicine [2].

However, data from domestic works indicate that for adequate application of any of the cephalometric methods of analysis, it is necessary to preadapt the data on a particular method for the local population, taking into account gender, age, regional affiliation [3, 4] and face type. [5].

The aim of the study was to establish the features and sex differences of cephalometric parameters according to the Steiner method in Ukrainian young men and young women with orthognathic occlusion and different face types.

\section{Materials and methods}

According to the Steiner method, a cephalometric study was performed on 49 young men and 76 young women with orthognathic occlusion in OnyxCeph $^{3 \mathrm{TM}}$ software, 3DPro version, Image Instruments $\mathrm{GmbH}$, Germany (license № URSQ-1799). Cephalometric points were determined by Phulari B. S. [6] and Doroshenko S. I., Kulginsky E. A. [7].

Determination of facial type (Table 1) was performed using the Garson index [8].

Table 1. Quantitative distribution of young men and young women by face types.

\begin{tabular}{|l|c|c|}
\hline \multicolumn{1}{|c|}{ Face types } & Young men & Young women \\
\hline Very wide & 5 & 25 \\
\hline Wide & 22 & 25 \\
\hline Average & 11 & 10 \\
\hline Narrow & 8 & 12 \\
\hline
\end{tabular}

Cephalometric parameters were divided into three groups according to Dmitriev M. O. [9]. The first group (parameters used in cephalometric analyzes by Schwartz, Ricketts, Steiner, Roth-Jarabak, Burstone and Bjork), which includes indicators that do not usually change during surgical and orthodontic treatment, is described in our previous studies [10].

Indicators of the upper and lower jaws belonging to the second group according to the Steiner method [11] are shown in Figure 1. 


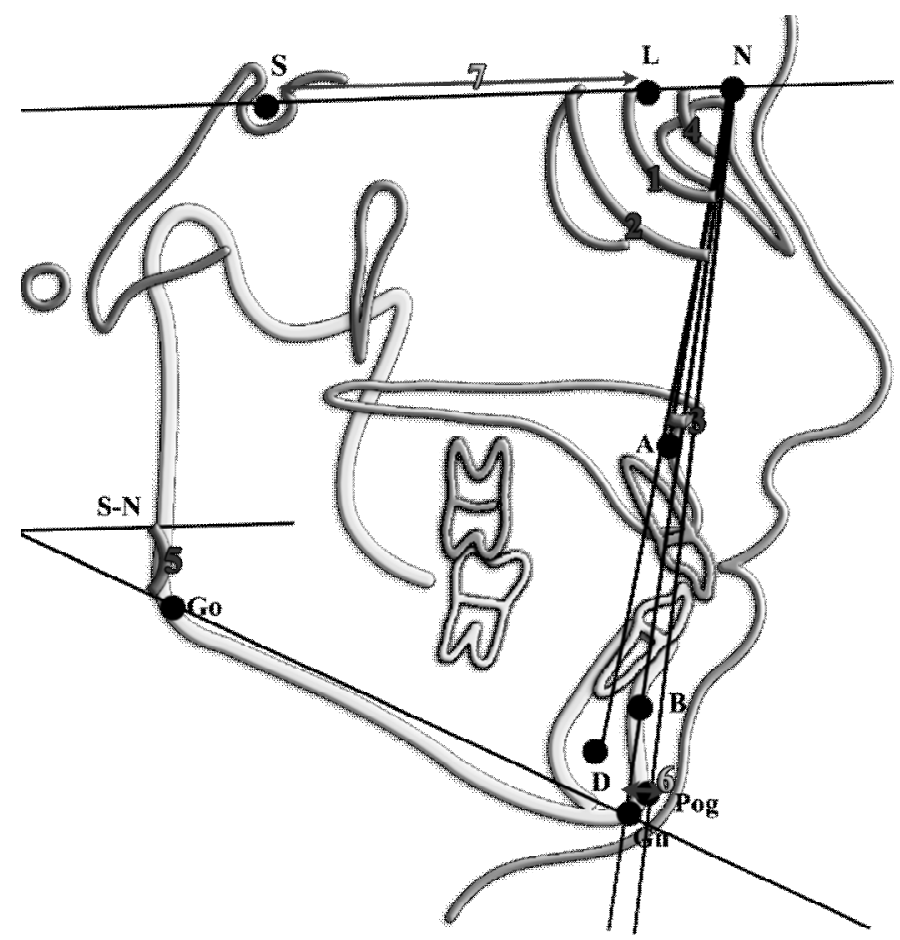

Fig. 1. The main cephalometric points and measurements according to Steiner included in the second group of indicators:

1 - SNA angle formed by lines $S-N$ and $N-A\left(^{\circ}\right) ; 2$ - angle SNB formed by lines $S-N$ and $N-B\left({ }^{\circ}\right) ; 3$ - angle ANB, formed by lines $A-N$ and $N-B\left({ }^{\circ}\right) ; 4-$ angle $S N D$ formed by lines $S-N$ and $N-D\left({ }^{\circ}\right) ; 5-$ angle $S N-G o G n$, formed by lines $S-N$ and Go-Gn ( $\left.{ }^{\circ}\right) ; 6$ - distance Pog-NB, the distance from the point Pog to the line N-B $(\mathrm{mm})$;

7 -distance $S-L$, the distance from the point $S$ to the structural point $L$, which is formed at the intersection of the perpendicular drawn from the point Pog to the line S-N ( $\mathrm{mm})$.

Indicators that characterize the position of each individual tooth relative to each other, cranial struc(included in the third group) according to the tures and the profile of the soft tissues of the face

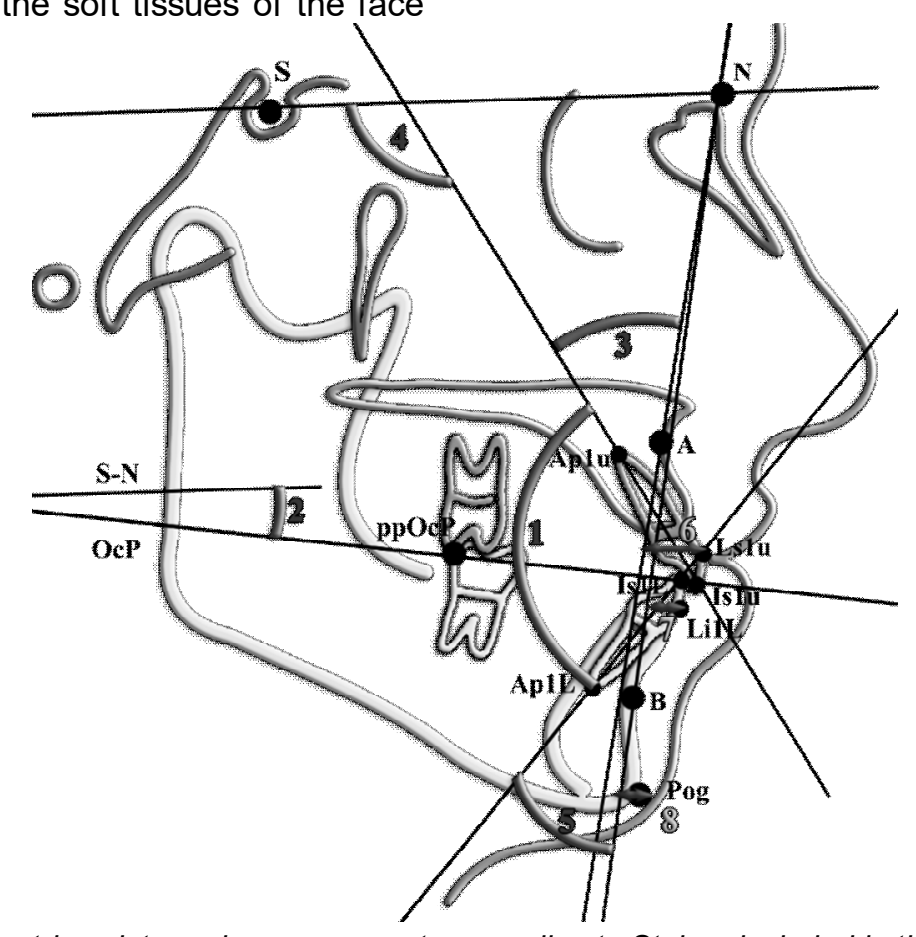

Fig. 2. The main cephalometric points and measurements according to Steiner included in the third group of indicators: 1 - angle II, formed by the central axes of the upper and lower medial incisors, namely the lines Ap1U-Is1u and Ar1LIs $1 L$ ( ${ }^{\circ}$ ); 2 - angle SN-OcP, formed by lines S-N and OcP ( $\left.{ }^{\circ}\right) ; 3$ - angle Max1-NA formed by the central axis of the upper medial incisor, namely the line Ap1u-Is1 $u$ and the line N-A ( $\left.{ }^{\circ}\right) ; 4-$ angle Max1-SN, formed by the central axis of the upper medial incisor, namely the line Ap1u-ls1u and the line S-N ( ${ }^{\circ}$ ); 5 - angle Mand1-NB, formed by the central axis of the lower medial incisor, namely the line Ap1L-Is1L and the line $N-B\left({ }^{\circ}\right) ; 6$ - distance $1 u$-NA, the distance

from the point Ls1u to the line $N-A(\mathrm{~mm}) ; 7$ - distance 1I-NB, the distance from the point Li1L to the line $N-B(\mathrm{~mm})$; 8 - Pog-NB distance, which belongs to the second group of indicators, is required to determine the Holdaway Ratio - the difference between the values of 11-NB and Pog-NB ( $\mathrm{mm})$. 
Statistical processing of teleradiographic indicators was performed in the license package "Statistica 6.0" using non-parametric evaluation methods. The significance of the difference in values between the indicators was determined using the U-test of Mann-Whitney.

\section{Research results and their discussion}

When comparing the value of the SNA angle, which characterizes the position of the upper jaw, namely the anterior contour, in the sagittal plane, between young women with different face types, it was found that the value of this indicator only in women with a very wide face type $\left(82.62 \pm 3.72^{\circ}\right)$ tends $(p=0.055)$ to higher values than in young women with an average face $\left(80.36 \pm 2.64^{\circ}\right)$.

When comparing the value of the angle SNB, which characterizes the position of the lower jaw, namely the anterior contour of the chin, in the sagittal plane, between young women with different face types, it was found that the value of this indicator in women with a very wide face type $\left(81.63 \pm 3.51^{\circ}\right)$ is significantly $(p<0.05)$ greater than in young women with a medium face $\left(78.40 \pm 2.07^{\circ}\right)$ and tends $(p=0.069)$ to higher values than in young women with a narrow face $\left(79.70 \pm 3.08^{\circ}\right)$.

When comparing the value of the angle ANB, which characterizes the position of the lower jaw relative to the upper jaw, in the boom plane, between young women with different face types, it was found that the value of this indicator in women with a very wide face type $\left(0.992 \pm 1.945^{\circ}\right)(p<0.05)$ is smaller than in young women with a narrow face $\left(2.783 \pm 1.842^{\circ}\right)$ and tends $(p=0.064)$ to lower values than in young women with a wide face $\left(2.164 \pm 2.399^{\circ}\right)$. When comparing the value of the ANB angle between young men and young women with the same face types, it was found that in young men with a very wide face type $\left(2.800 \pm 1.210^{\circ}\right)$ the value of this indicator is significantly $(p<0.05)$ greater.

When comparing the value of the angle SND, which characterizes the position of the lower jaw, namely the center of the chin, in the sagittal plane, between young women with different face types, it was found that the value of this indicator in representatives with a very wide face $\left(79.39 \pm 3.27^{\circ}\right)$ $(p<0.05-0.01)$ is greater than in young women with wide $\left(77.62 \pm 3.60^{\circ}\right)$, medium $\left(76.05 \pm 2.31^{\circ}\right)$ and narrow $\left(77.13 \pm 3.27^{\circ}\right)$ types of faces.

When comparing the value of the angle $\mathrm{SN}$ GoGn, which characterizes the inclination of the lower jaw relative to the anterior cranial base $\mathrm{S}-\mathrm{N}$, between young men with different face types found that the value of this indicator only in the middle face $\left(28.07 \pm 5.40^{\circ}\right)$ tends $(p=0.069)$ to higher values than in young men with a narrow face type $\left(23.66 \pm 5.72^{\circ}\right)$; between young women with different face types, it was found that the value of this indicator in women with a very wide face $\left(25.04 \pm 4.65^{\circ}\right)$ is significantly $(p<0.05-0.001)$ lower than in young women with a wide $\left(27.92 \pm 4.66^{\circ}\right)$, medium $\left(31.70 \pm 4.56^{\circ}\right)$ and narrow $\left(31.28 \pm 3.55^{\circ}\right)$ face types, and in young women with a wide face - significantly $(p<0.05)$ less than in young women with medium and narrow face types. When comparing the value of the SN-GoGn angle between young men and young women with the same face types, it was found that young women with a narrow face the value of this indicator is significantly $(p<0.05)$ greater.

When comparing the value of the Pog-NB distance, which characterizes the position of the anterior contour of the bony chin relative to the N-B line, between young women with different face types, it was found that the value of this indicator only in women with a very wide face type $(2.840 \pm 1.650$ $\mathrm{mm})(\mathrm{p}<0.05)$ is larger than in young women with a wide face $(1.600 \pm 1.756 \mathrm{~mm})$. When comparing the value of the Pog-NB distance between young men and young women with the appropriate facial types, it was found that young men with wide $(2.818 \pm 1.622 \mathrm{~mm})$ and narrow $(3.750 \pm 1.832 \mathrm{~mm})$ facial types, the value of this indicator is significantly $(p<0.05)$ greater (in young women with a narrow face $-1.833 \pm 1.193 \mathrm{~mm}$ ).

When comparing the value of the distance S-L, which characterizes the position of the anterior contour of the mandible, between young women with different face types, it was found that the value of this indicator in women with a very wide face $(55.76 \pm 8.74 \mathrm{~mm})$ significantly $(p<0.05-0.001)$ is greater than in young women with wide $(51.36 \pm 9.30$ $\mathrm{mm})$, medium $(46.30 \pm 5.42 \mathrm{~mm})$ and narrow $(48.75 \pm 5.77 \mathrm{~mm})$ facial types. When comparing the value of the distance S-L between young men and young women with the appropriate face types, it was found that young men with wide $(56.32 \pm 9.33$ $\mathrm{mm})$, medium $(54.09 \pm 6.66 \mathrm{~mm})$ and narrow $(57.63 \pm 9.77 \mathrm{~mm})$ facial types, the value of this indicator is significantly $(p<0.05-0.01)$ greater.

Thus, when comparing between young men or young women with orthognathic occlusion with different types of faces cephalometric parameters by the Stainer method, belonging to the second group of indicators, pronounced differences are found only between young women, namely - in women with a very wide face type significantly larger, or tendencies to higher values of SNA (compared to medium face), SNB (compared to medium and narrow face types) and SND (compared to other face types) and distances Pog-NB (compared to wide face) and S-L (compared to other face types), as well as smaller values of the angles ANB (compared to wide and narrow face types) and SNGoGn (compared to other face types). The pronounced manifestations of sexual dimorphism of cephalometric parameters by the Stainer method, belonging to the second group of indicators, are established only for linear indicators: in young men with wide and narrow facial types significantly greater Pog-NB distance, and in young men with wide, medium and narrow facial types - larger values of the distance S-L. Among the angular values, young men with a very wide face had only a significantly higher value of the ANB angle, and young 
women with a narrow face had a higher value of the SN-GoGn angle.

When comparing the value of the angle II, which characterizes the characteristic slope of the upper and lower medial incisors relative to each other, between young men with different face types found that the value of this indicator only in representatives with a narrow face type $\left(137.3 \pm 5.5^{\circ}\right)$ reliably $(p<0.05)$ is greater than in young men with a wide face $\left(131.0 \pm 6 \cdot 1^{\circ}\right)$.

When comparing the value of the angle SN$\mathrm{OcP}$, which characterizes the slope of the closing plane relative to the anterior cranial base $\mathrm{S}-\mathrm{N}$, between young women with different face types, it was found that the value of this indicator in representatives with a very wide face $\left(12.79 \pm 4.17^{\circ}\right)$ reliably $(p<0.05-0.01)$ is smaller than in young women with medium $\left(17.73 \pm 3.74^{\circ}\right)$ and narrow $\left(16.02 \pm 2.73^{\circ}\right)$ facial types. When comparing the $\mathrm{SN}-\mathrm{OcP}$ angle between young men and young women with the same face types, it was found that in young women with a narrow face type the value of this indicator tends $(p=0.064)$ to higher values (in young men $11.83 \pm 4.72^{\circ}$ ).

When comparing the value of the angle Max1NA, which characterizes the position of the upper medial incisor to the line $\mathrm{N}-\mathrm{A}$, between young men with different face types, it was found that the value of this indicator in representatives with a wide face $\left(22.27 \pm 5.93^{\circ}\right)$ tends $(p=0.064)$ to higher values than in young men with average face type $\left(18.25 \pm 6.02^{\circ}\right)$; between young women with different face types it was found that the value of this indicator in women with a very wide face $\left(24.26 \pm 5.75^{\circ}\right)$ is significantly $(p<0.05)$ greater than in young women with a narrow face type $\left(19.33 \pm 7.48^{\circ}\right)$. When comparing the value of the angle Max1-NA between young men and young women with the same face types, it was found that in young women with average face type, the value of this indicator $\left(22.22 \pm 3.86^{\circ}\right)$ tends $(p=0.067)$ to higher values.

When comparing the value of the angle Max1$\mathrm{SN}$, which characterizes the position of the medial incisor to the anterior cranial base $\mathrm{S}-\mathrm{N}$, between young men with different face types found that the value of this indicator in representatives with a wide face $\left(105.7 \pm 7.7^{\circ}\right)$ tends $(p=0.059)$ to higher values than in young men with average face type $\left(100.8 \pm 5.5^{\circ}\right)$; between young women with different face types it was found that the value of this indicator in women with a very wide face $\left(106.9 \pm 6.8^{\circ}\right)$ is significantly $(p<0.05)$ greater than in young women with average $\left(102.6 \pm 2.9^{\circ}\right)$ and narrow $\left(101.8 \pm 6.5^{\circ}\right)$ facial types.

When comparing the value of the distance $1 \mathrm{u}$ NA, which characterizes the position of the crown of the upper medial incisor in the boom plane relative to the line $\mathrm{N}-\mathrm{A}$, it was found that in young women with a very wide face type the value of this indicator $(5.320 \pm 1.773 \mathrm{~mm})$ tends $(p=0.079)$ values (in young men $3.800 \pm 1.304 \mathrm{~mm}$ ).

When comparing the value of the distance 1INB, which characterizes the position of the crown of the lower medial incisor in the sagittal plane relative to the line $\mathrm{N}-\mathrm{B}$, between young men with different face types found that the value of this indicator in representatives with a wide face $(4.591 \pm 1.532 \mathrm{~mm})$ reliably $(p<0.05)$ greater than in young men with a narrow face type $(3.125 \pm 1.553 \mathrm{~mm})$; between young women with different face types, it was found that the value of this indicator in women with a very wide face $(3.440 \pm 1.474 \mathrm{~mm})$ is significantly $(p<0.05)$ lower, or tends $(p=0.070)$ to lower values than in young women with wide $(4.440 \pm 1.781 \mathrm{~mm})$, medium $(4.700 \pm 1.636 \mathrm{~mm})$ and narrow $(4.417 \pm 0.900 \mathrm{~mm})$ facial types. When comparing the value of the distance 1I-NB between young men and young women with the same face types, it was found that young women with a narrow face type, the value of this indicator is significantly $(p<0.05)$ greater.

When comparing the distance Holdaway Ratio, which characterizes the position of the crown of the lower medial incisor in the sagittal plane relative to the bony chin Pog, between young men with different face types found that the value of this indicator only in broad-faced $(1.818 \pm 2.032 \mathrm{~mm})$ reliably $(p<0.05)$ is greater than in young men with a narrow face type $(-0.750 \pm 2.964 \mathrm{~mm})$; between young women with different face types, it was found that the value of this indicator in women with a very wide face $(0.520 \pm 2.434 \mathrm{~mm})$ is significantly $(p<0.05)$ lower than in young women with a wide $(2.640 \pm 3.174 \mathrm{~mm})$, medium $(3.000 \pm 2.582 \mathrm{~mm})$ and narrow $(2.583 \pm 1.564 \mathrm{~mm})$ face types. When comparing the value of the distance of the Holdaway Ratio between young men and young women with the same face types, it was found that young women with a narrow face, the value of this indicator is significantly $(p<0.05)$ greater.

The value of the angle Mand1-NB, which characterizes the position of the lower medial incisor to the line $\mathrm{N}-\mathrm{B}$, has no significant or tendency differences between young men or young women with different face types and between young men and young women with the same face types.

Thus, when comparing between young men or young women with orthognathic occlusion with different types of faces cephalometric parameters by the Stainer method, belonging to the third group of indicators, more pronounced differences are also found between young women, namely - in women with a very wide face type significantly larger, or tendencies to larger values of Max1-NA (compared to narrow face) and Max1-SN (compared to medium and narrow face types), as well as smaller values of Holdaway Ratio and 1I-NB distances (compared to other face types) and SN-OcP angle values (compared to medium and narrow face types). Among young men, most of the reliable, or trends in differences in cephalometric parameters by the Stainer method, belonging to the third group of indicators are established with representatives of a wide type of face - larger values of distances Holdaway Ratio and 1I-NB (compared to a narrow face) and angles Max1-NA and Max1 -SN (com- 
pared to the average face), as well as smaller values of the angle II (compared to the narrow face). Manifestations of sexual dimorphism of cephalometric parameters by the Stainer method, belonging to the third group of indicators, are established as for linear - in young women with a narrow face type significantly greater values of Holdaway Ratio and $1 \mathrm{l}-\mathrm{NB}$, and in young women with a very wide face type tend to greater distance values 1I-NA; and for angular indicators - in young women with a narrow face type there is a tendency to larger values of the SN-OcP angle, and in young women with a medium face type there is a tendency to larger values of the Max1-NA angle.

Cephalometric analysis is actively used to assess congenital genetic diseases. The team of authors found [12] that individuals with BlochSulzberger syndrome have mostly skeletal class II (found in $44.4 \%$ of subjects) and in comparison with healthy individuals have lower values of the right maxillary width.

No less important are the works aimed at adapting cephalometric indicators for the local population. Pierre O. Z. and co-authors [13] established normative cephalometric parameters for Cameroonians by the Stainer method. Compared to the norm, the people of Cameroon have lower values of inter-incisor and SND angles $\left(119.3^{\circ}\right.$ and $78.8^{\circ}$, respectively).

Vedprakash S.R. and others [14] adapted the Stainer cephalometric method for Indians. The study involved 1,200 people aged $25-45$ years. Statistical analysis of the results showed that compared to Stainer, the population of India, like the population of Cameroon, has lower values of interincisor and SND angles $\left(118.3^{\circ}\right.$ and $68.8^{\circ}$, respectively, with Stainer $131^{\circ}$ and $79^{\circ}$, respectively).

However, as shown by foreign studies, it is equally important to take into account the type of face during cephalometric analysis [15-18] and the use of modern technologies to improve accuracy and facilitate the process of obtaining data [19].

It is known that the type of face significantly affects the structure of the upper and lower jaws. Individuals with a hyperdivergent facial type have a greater alveolar height of both jaws, a greater postalveolar height of the upper jaw, a longer and narrower symphysis, and a greater depth of the antegonial notch [20].

Individuals with a long narrow face type have higher rates of gum recession and periodontal connective tissue loss (facial index, $P$ for trend $=0.02$ and $p=0.01$, respectively), especially for incisors and canines [21].

A group of scientists led by Řeháček A. [22] determined the normative cephalometric indicators for the population of the Czech Republic, taking into account the type of human face. Based on the obtained statistical data, the authors built mathematical models using the following cephalometric indicators: SNA, SNB, NL-NSL, ML-NSL and NSBa.

The peculiarities of Stainer cephalometric parameters obtained by us in Ukrainian young men and young women with orthognathic occlusion with different types of faces are the normative base that will allow dentists to improve the results of work with the appropriate contingents of patients.

\section{Conclusions}

In Ukrainian young men or young women with orthognathic occlusion, numerous reliable and tendencies of differences of cephalometric parameters according to the Stainer method have been established in representatives with different face types. Among the indicators belonging to the second group, significant differences were found only between young women with a very wide face and other types of faces. Among the indicators belonging to the third group, more pronounced differences were also found between young women with a very wide face and other types of faces; among young men - with representatives with a wide face compared to the middle and narrow face types.

Among the Stainer cephalometric parameters belonging to the second group of indicators, the expressed manifestations of sexual dimorphism of cephalometric parameters are established only for linear indicators; among the parameters belonging to the third group of indicators, the manifestations of sexual dimorphism are established for both linear and angular indicators.

\section{Prospects for further research}

In further studies in young men and young women with orthognathic occlusion, depending on the type of face, it is planned to assess the percentile range, features and sex differences of cephalometric parameters by Downs method.

\section{References}

1. Narayanan RK, Jeseem MT, Kumar TA. Prevalence of malocclusion among 10-12-year-old schoolchildren in Kozhikode District, Kerala: An epidemiological study. International journal of clinical pediatric dentistry. 2016 Jan; 9(1): 50-55. https://doi.org/10.5005/jp-journals-10005-1333

2. Dmitriev M, Gunas V, Polishchuk S, Olkhova I, Kumar A. Modeling of Central Incisors Position Indicators in boys and girls according to CC. Steiner method for Forensic Dental Identification. The Official Publication of Indian Academy of Forensic Medicine. 2020 Jul; 42(3): 155-60. https://doi.org/10.5958/0974-0848.2020.00043.3

3. Soboń JS, Cherkasova OV, Gunas VI, Babych LV, Kotsyura OO. Correlations of linear sizes of molars with cephalometric indicators of practically healthy men of the southern region of Ukraine. Biomedical and Biosocial Anthropology. 2020 Sep; 30(38): 3646. https://doi.org/10.31393/bba38-2020-06

4. Gunas VI, Kotsyura OO, Babych LV, Shevchuk YG, Cherkasova OV. Features correlations of the sizes of molars with cephalometric indicators of men of the western region of Ukraine. Reports of Morphology. 2020 Oct 12; 26(2): 51-61. https://doi.org/10.31393/morphology-journal-202026(2)-08

5. Marchenko AV, Shinkaruk-Dykovytska MM, Pozur TP, Gunas VI, Orlovskiy VO. Models of individual linear dimensions necessary for the construction of 
the correct form of dental arches in young men with a wide face, depending on the features of odontometric and cephalometric indicators. Wiadomosci lekarskie (Warsaw, Poland: 1960). 2020; 73(6): 1103-7. https://doi.org/10.36740/WLek202006104

6. Phulari B. An atlas on cephalometric landmarks. JP Medical Ltd; 2013. 230 p.

7. Doroshenko SI, Kulginskii EA. Osnovy telerentgenografii. K., Zdorov'ya; 2007. 72 s. (Russian).

8. Profit WR. Sovremennaya ortodontiya (4-e izd., per. s angl.). M.: MEDpress-inform; 2015. 560 s. (Russian).

9. Dmitriev MO. Zviazky osnovnykh kranialnykh pokaznykiv z kharakterystykamy polozhennia zubiv verkhnoi i nyzhnoi shchelep ta profilem miakykh tkanyn oblychchia $v$ yunakiv i divchat. Visnyk morfolohii. 2017; 23(1): 125-31. (Ukrainian).

10. Drachevska IYu, Dmitriev MO, Perera Clifford, Shevchenko VM, Gunas IV. Determination of cephalometric parameters, which usually do not change during surgical and orthodontic treatment depending on facial types in Ukrainian young men and young women with orthognathic occlusion. Biomedical and Biosocial Anthropology. 2020; 41: 18-23.

11. Steiner CC. Cephalometrics in clinical practice. Angle Orthod. 1959; 29: 8-29.

12. Maahs MA, Kiszewski AE, Rosa RF, Santa Maria FD, Prates FB, Zen PR. Cephalometric skeletal evaluation of patients with Incontinentia Pigmenti. Journal of oral biology and craniofacial research. 2014 May 1; 4(2): 88-93. https://doi.org/10.1016/j.jobcr.2014.05.002

13. Pierre OZ, Charles $B$, Catherine $E$, Jules $O$. Cephalometric Characteristics of Cameroonian Adults: Dimensional Analysis of 80 Cases. Dentistry. $2020 \quad$ Mar 20; 10(3): 1-4. https://doi.org/10.36349/easjdom.2019.v01i06.003

14. Vedprakash SR, Mustafa M, Subhash V, Sharma P. Cephalometric characteristics of Indian adults: with special reference to Delhi NCR hospital. European Journal of Molecular \& Clinical Medicine. 2021; 8(04): 645-52.

15. Rajawat I, Venkataramana V, Patil P, Guram G, Gupta N, Lau M, Thakkar P, Shah DM. A cephalometric evaluation for co-relation of different facial types with occlusal plane in dentulous and edentulous patients. OHDM. December. 2014; 13(4): 116-20. https://doi.org/10.4103/1305-7456.175694

16. Rana T, Khanna R, Tikku T, Sachan K. Relationship of maxilla to cranial base in different facial types-a cephalometric evaluation. Journal of oral biology and craniofacial research. 2012 Jan 1; 2(1): 30-5. https://doi.org/10.1016/S2212-4268(12)60008-6

17. Prasad PN, Ansari R, Rana T, Rawat N. Assessment of Beta Angle among the various Facial Types in Garhwali Population-A Cephalometric Evaluation. Orthodontic Journal of Nepal. 2013 Dec 6; 3(1): 37-40.

18. Sidiropoulou S. Study of craniofacial relations and facial types in Greek population with normal occlusion. Balkan Journal of Dental Medicine. 2015; 19(3): 13240. https://doi.org/10.1515/bjdm-2015-0048

19. Valletta R, Pango A, Tortora G, Rongo R, Simeon $\mathrm{V}$, Spagnuolo G, D'Antò V. Association between gingival biotype and facial typology through cephalometric evaluation and three-dimensional facial scanning. Applied Sciences. 2019 Jan; 9(23): 5057. https://doi.org/10.3390/app9235057

20. Roy AS, Tandon P, Chandna AK, Sharma VP, Nagar A, Singh GP. Jaw morphology and vertical facial types: a cephalometric appraisal. Journal of Orofacial Research. 2012; 131-8.

21. Salti L, Holtfreter B, Pink $C$, Habes M, Biffar $R$, Kiliaridis S, Krey KF, Bülow R, Völzke H, Kocher T, Daboul A. Estimating effects of craniofacial morphology on gingival recession and clinical attachment loss. Journal of clinical periodontology. 2017 Apr; 44(4): 363-71. https://doi.org/10.1111/jcpe.12661

22. Řeháček $A$, Janega M, Hofmanova P, Dostalova T. Cephalometric floating norms for Czech adults. Prague medical report. 2012 Jan 1; 113(4): 271-8.

\section{Список літератури}

1. Narayanan RK, Jeseem MT, Kumar TA. Prevalence of malocclusion among 10-12-year-old schoolchildren in Kozhikode District, Kerala: An epidemiological study. International journal of clinical pediatric dentistry. 2016 Jan; 9(1): 50-5. https://doi.org/10.5005/jp-journals-10005-1333

2. Dmitriev M, Gunas V, Polishchuk S, Olkhova I, Kumar A. Modeling of Central Incisors Position Indicators in boys and girls according to CC. Steiner method for Forensic Dental Identification. The Official Publication of Indian Academy of Forensic Medicine. 2020 Jul; $42(3)$ : 155-60. https://doi.org/10.5958/0974-0848.2020.00043.3

3. Soboń JS, Cherkasova OV, Gunas VI, Babych LV, Kotsyura OO. Correlations of linear sizes of molars with cephalometric indicators of practically healthy men of the southern region of Ukraine. Biomedical and Biosocial Anthropology. 2020 Sep; 30(38): 3646. https://doi.org/10.31393/bba38-2020-06

4. Gunas VI, Kotsyura OO, Babych LV, Shevchuk YG, Cherkasova OV. Features correlations of the sizes of molars with cephalometric indicators of men of the western region of Ukraine. Reports of Morphology. 2020 Oct 12; 26(2): 51-61. https://doi.org/10.31393/morphology-journal-202026(2)-08

5. Marchenko AV, Shinkaruk-Dykovytska MM, Pozur TP, Gunas VI, Orlovskiy VO. Models of individual linear dimensions necessary for the construction of the correct form of dental arches in young men with a wide face, depending on the features of odontometric and cephalometric indicators. Wiadomosci lekarskie (Warsaw, Poland: 1960). 2020; 73(6): 1103-7. https://doi.org/10.36740/WLek202006104

6. Phulari B. An atlas on cephalometric landmarks. JP Medical Ltd; 2013. 230 p.

7. Дорошенко СИ, Кульгинский ЕА. Основы телерентгенографиии. К., Здоров'я; 2007. 72 с.

8. Профит УР. Современная ортодонтия (4-е изд., пер. с англ.). М.: МЕДпресс-информ; 2015. 560 с.

9. Дмітрієв МО. Зв'язки основних краніальних показників з характеристиками положення зубів верхньої і нижньої щелеп та профрілем м'яких тканин обличчя в юнаків і дівчат. Вісник морфології. 2017; 23(1): 125-31.

10. Drachevska IYu, Dmitriev MO, Perera Clifford, Shevchenko VM, Gunas IV. Determination of cephalometric parameters, which usually do not 
change during surgical and orthodontic treatment depending on facial types in Ukrainian young men and young women with orthognathic occlusion. Biomedical and Biosocial Anthropology. 2020; 41: 18-23.

11. Steiner CC. Cephalometrics in clinical practice. Angle Orthod.. 1959; 29: 8-29.

12. Maahs MA, Kiszewski AE, Rosa RF, Santa Maria FD, Prates FB, Zen PR. Cephalometric skeletal evaluation of patients with Incontinentia Pigmenti. Journal of oral biology and craniofacial research. 2014 May 1; 4(2): 88-93. https://doi.org/10.1016/j.jobcr.2014.05.002

13. Pierre OZ, Charles B, Catherine E, Jules O. Cephalometric Characteristics of Cameroonian Adults: Dimensional Analysis of 80 Cases. Dentistry. $2020 \quad$ Mar 20; 10(3): 1-4. https://doi.org/10.36349/easjdom.2019.v01i06.003

14. Vedprakash SR, Mustafa M, Subhash V, Sharma P. Cephalometric characteristics of Indian adults: with special reference to Delhi NCR hospital. European Journal of Molecular \& Clinical Medicine. 2021; 8(04): 645-52.

15. Rajawat I, Venkataramana V, Patil P, Guram G, Gupta N, Lau M, Thakkar P, Shah DM. A cephalometric evaluation for co-relation of different facial types with occlusal plane in dentulous and edentulous patients. OHDM. December. 2014; 13(4): $\quad 116-20 . \quad$ https://doi.org/10.4103/13057456.175694

16. Rana T, Khanna R, Tikku T, Sachan K. Relationship of maxilla to cranial base in different facial types-a cephalometric evaluation. Journal of oral biology and craniofacial research. 2012 Jan $1 ; 2(1): 30-5$. https://doi.org/10.1016/S2212-4268(12)60008-6

17. Prasad PN, Ansari R, Rana T, Rawat $\mathrm{N}$ Assessment of Beta Angle among the various Facial Types in Garhwali Population-A Cephalometric Evaluation. Orthodontic Journal of Nepal. 2013 Dec 6; 3(1): 37-40.

18. Sidiropoulou S. Study of craniofacial relations and facial types in Greek population with normal occlusion. Balkan Journal of Dental Medicine. 2015; 19(3): 13240. https://doi.org/10.1515/bjdm-2015-0048

19. Valletta R, Pango A, Tortora G, Rongo R, Simeon V, Spagnuolo G, D'Antò V. Association between gingival biotype and facial typology through cephalometric evaluation and three-dimensional facial scanning. Applied Sciences. 2019 Jan; 9(23): 5057. https://doi.org/10.3390/app9235057

20. Roy AS, Tandon P, Chandna AK, Sharma VP, Nagar A, Singh GP. Jaw morphology and vertical facial types: a cephalometric appraisal. Journal of Orofacial Research. 2012; 131-8.

21. Salti L, Holtfreter B, Pink C, Habes M, Biffar R, Kiliaridis S, Krey KF, Bülow R, Völzke H, Kocher T, Daboul A. Estimating effects of craniofacial morphology on gingival recession and clinical attachment loss. Journal of clinical periodontology. 2017 Apr; 363-71. https://doi.org/10.1111/jcpe.12661

22. Řeháček $A$, Janega $M$, Hofmanova $P$, Dostalova $T$. Cephalometric floating norms for Czech adults. Prague medical report. 2012 Jan 1; 113(4): 271-8.

Стаття надійшла 16.11.2021 p.

\title{
Summary
}

In Ukrainian young men $(n=49)$ or young women $(n=76)$ with orthognathic occlusion with different face types, numerous reliable and tendencies of differences of cephalometric parameters by the Stainer method were established. Among the indicators belonging to the second group (indicators of the upper and lower jaws according to the Steiner method), significant differences were found only between young women with a very wide face and other types of faces. Among the indicators belonging to the third group (indicators by the Steiner method that characterize the position of each individual tooth relative to each other, cranial structures and soft tissue profile of the face), more pronounced differences are also found between young women with very wide faces and other facial types; among young men - with representatives with a wide face compared to the middle and narrow face types. Among the cephalometric parameters belonging to the second group of indicators, the expressed manifestations of sexual dimorphism of cephalometric parameters are established only for linear indicators; among the parameters belonging to the third group of indicators, the manifestations of sexual dimorphism are established for both linear and angular indicators.

Key words: cephalometry according to the Steiner method, Ukrainian young men and young women with orthognathic occlusion, face types, sex differences.

\section{ВИЗНАЧЕННЯ НОРМАТИВНИХ ЦЕФАЛОМЕТРИЧНИХ ПАРАМЕТРІВ МЕТОДОМ STEINER ДЛЯ УКРАЇНСЬКИХ ЮНАКІВ I ДIВЧАТ IЗ РІЗНИМИ ТИПАМИ ОБЛИЧЧЯ}

\author{
Драчевська I.Ю., Дмітрієв М.О., Попова О.І., Чугу Т.В., Гунас I.В. \\ Вінницький національний медичний університет ім. М.І. Пирогова, Вінниця, Україна
}

\section{Резюме}

Створення ідеальної усмішки - складний і тривалий процес, що вимагає застосування великого обсягу знань із боку лікаря й фінансових витрат із боку пацієнта. Допущення помилок чи неточностей на етапі планування ортодонтичного втручання може зіграти ключову роль у спотворенні остаточних ре- 
зультатів. Аби уникнути такої ситуації, сучасний лікар-ортодонт мусить мати на своєму озброєнні сучасний арсенал достовірних і адекватних методів планування ортодонтичного лікування. Одним із таких інструментів визнано цефалометричний аналіз - метод, що базується на вивченні специфічних орієнтирів і точок, проте водночас потребує адаптації для успішного його застосування в практиці українського ортодонта.

Мета роботи - установити особливості й статеві розбіжності цефалометричних параметрів методом Steiner в українських юнаків і дівчат із ортогнатичним прикусом із різними типами обличчя.

За методикою Steiner проведено цефалометричне дослідження 49 юнакам і 76 дівчатам із ортогнатичним прикусом у програмному забезпеченні «OnyxCeph ${ }^{3 \mathrm{TM} », ~ в е р с і і ̈ ~ « 3 D P r o », ~ к о м п а н і і ̈ ~ « I m a g e ~}$ Instruments GmbH», Німеччина (ліцензія № URSQ-1799). Розподіл на типи обличчя проводили за допомогою індексу Гарсона. У ліцензійному статистичному пакеті "Statistica 6,0" із використанням непараметричних методів оцінки проведено аналіз другої (показники верхньої й нижньої щелеп за методом Steiner) і третьої (показники за методом Steiner, які характеризують положення кожного окремого зуба відносно один одного, черепних структур і профілю м'яких тканин обличчя) груп показників.

При порівнянні між юнаками або дівчатами з ортогнатичним прикусом із різними типами обличчя цефалометричних параметрів за методом Stainer, що належать до другої групи показників, у дівчат із дуже широким типом обличчя встановлено достовірно більші, або тенденції до більших значень величини кутів SNA (порівняно із середнім обличчям), SNB (порівняно із середнім і вузьким типами обличчя) і SND (порівняно з іншими типами обличчя) та відстаней Pog-NB (порівняно з широким обличчям) i S-L (порівняно з іншими типами обличчя), а також менші значення величини кутів ANB (порівняно з широким і вузьким типами обличчя) і SN-GoGn (порівняно з іншими типами обличчя). Установлено виражені прояви статевого диморфізму параметрів, що належать другої групи показників: в юнаків із широким і вузьким типами обличчя достовірно більші значення відстані Pog-NB, а в юнаків із широким, середнім і вузьким типами обличчя - більші значення відстані S-L; в юнаків із дуже широким обличчям - достовірно більше значення кута ANB, а в дівчат із вузьким обличчям - більше значення кута SN-GoGn. При порівнянні цефралометричних параметрів за методом Stainer, що належать до третьої групи показників, у дівчат із дуже широким типом обличчя встановлено достовірно більші, або тенденції до більших значень величини кутів Max1-NA (порівняно з вузьким обличчям) і Max1-SN (порівняно з середнім і вузьким типами обличчя), а також менші значення величини відстаней Holdaway Ratio i 1I-NB (порівняно з іншими типами обличчя) і величини кута SN-OcP (порівняно з середнім і вузьким типами обличчя); в юнаків із широким обличчям установлено більші значення відстаней Holdaway Ratio i 11-NB (порівняно з вузьким обличчям) і величини кутів Max1-NA і Max1-SN (порівняно з середнім обличчям), а також менші значення величини кута II (порівняно з вузьким обличчям). Установлені такі прояви статевого диморфізму параметрів, що належать до третьої групи показників: у дівчат із вузьким типом обличчя достовірно більші значення відстаней Holdaway Ratio i 1l-NB і тенденція до більших значень величини кута SN-OcP, у дівчат із дуже широким типом обличчя - тенденція до більших значень відстані 11-NA, а в дівчат із середнім типом обличчя - тенденція до більших значень величини кута Max1-NA.

Отже, в українських юнаків або дівчат із ортогнатичним прикусом установлено численні достовірні й тенденції розбіжностей цефалометричних параметрів за методом Stainer у представників із різними типами обличчя. Серед показників, що належать до другої групи, виражені розбіжності встановлено лише між дівчатами з дуже широким обличчям та іншими типами обличчя. Серед показників, що належать до третьої групи, більш виражені робіжності також установлено між дівчатами з дуже широким обличчям та іншими типами обличчя; серед юнаків - із представниками з широким обличчям порівняно із середнім і вузьким типами обличчя. Серед цефралометричних параметрів за методом Stainer, що належать до другої групи показників, виражені прояви статевого диморфізму цефалометричних параметрів установлено лише для лінійних показників; серед параметрів, що належать до третьої групи показників, прояви статевого диморфізму встановлено і для лінійних, і для кутових показників.

Перспектива досліджень - оцінка процентильного розмаху, особливостей і статевих розбіжностей у юнаків і дівчат із ортогнатичним прикусом залежно від типу обличчя цефалометричних параметрів за методом Downs.

Ключові слова: цефалометрія за методом Steiner, українські юнаки й дівчата з ортогнатичним прикусом, типи обличчя, статеві розбіжності. 